\title{
Effect of Fenugreek Seed Supplementation on Milk Yield and its Composition of Crossbred Dairy Cattle
}

\author{
P. Revathi", D. Anandha Prakash Singh ${ }^{1}$, V. Ramesh Saravana Kumar ${ }^{2}$, \\ A. K. Thiruvenkadan ${ }^{3}$ and N. Bharathy ${ }^{1}$
}

${ }^{1}$ Livestock Farm Complex, ${ }^{3}$ Department of Animal Genetics and Breeding, Veterinary College and Research Institute, Namakkal, (Tamil Nadu Veterinary and Animal Sciences University), Tamil Nadu, India

${ }^{2}$ Department of Livestock Production Management, Veterinary College and Research Institute, Tirunellveli, (Tamil Nadu Veterinary and Animal Sciences University), Tamil Nadu, India

*Corresponding author

\section{Keywords}

Fenugreek seed, Milk yield, Milk composition, Dairy cow

Article Info

Accepted:

07 August 2020

Available Online:

10 September 2020

\begin{abstract}
A B S T R A C T
Effect of fenugreek seed supplementation on milk yield and its composition were studied using twelve crossbred dairy cattle. While six cows were supplemented with soaked fenugreek seed, the rest were treated as control. The study period comprises of 30 days of pre-supplementation, 60 days of supplementation and 30 days of post-supplementation periods. The mean milk yield (litres) was significantly $(\mathrm{P}<0.05)$ higher with fenugreek supplementation $(8.93 \pm 0.16)$ as compared to pre-supplementation $(8.24 \pm 0.09)$ and postsupplementation $(8.37 \pm 0.22)$ periods. The total solids and SNF per cent during supplementation period $(13.51 \pm 0.07$ and $8.63 \pm 0.03)$ showed significantly higher values as compared to pre-supplementation (13.18 \pm 0.03 and $8.54 \pm 0.02)$ and postsupplementation $(13.19 \pm 0.05$ and $8.55 \pm 0.03)$ periods. The mean fat and protein per cent during supplementation period $(4.89 \pm 0.06$ and $3.22 \pm 0.01)$ were significantly $(\mathrm{P}<0.01)$ higher as compared to pre-supplementation $(4.64 \pm 0.02$ and $3.12 \pm 0.01)$ and postsupplementation $(4.64 \pm 0.03$ and $3.14 \pm 0.01)$ periods. This indicated the positive effect of fenugreek seed on milk yield and its composition.
\end{abstract}

\section{Introduction}

Milk production is an important rural activity in India providing supplementary income, employment and nutrition to millions of rural households. India has emerged as the largest milk producer in the world with an annual production of more than 121.8 million tonnes, giving a per capita availability of $281 \mathrm{~g}$ per day (National Dairy Development Board, 2012). However, India's productivity per animal compared with the global average is very low various management and disease conditions of the lactating animals are particularly responsible for low milk yield (Mishra et al., 2006). Use of galactogogues of herbal origin seems to reaffirm the milchherd health without causing deleterious 
alterations in the tissue reactions. Fenugreek (Trigonella foenum-graecum L.) is one of the oldest medicinal plant, dating back to Hippocrates and ancient Egyptian times (Jensen, 1992), is an annual herb from Papilionaceae Leguminosae family and is extensively cultivated in various parts of the world particularly in India, Middle East, Northern Africa and Southern Europe (Fotopoulos, 2002). The seeds of this herb have been used in traditional medicine to promote lactation in lactating women (ShaneMcWhorter, 2001 and Tiran, 2003). But, the galactogogue property of fenugreek seed supplementation has not been explored in crossbred dairy cattle in India. Hence, the present work was carried out to study the effect of fenugreek seed on milk yield and its composition on crossbred dairy cattle.

\section{Materials and Methods}

Twelve crossbred dairy cattle available at Livestock Farm, Department of Livestock Production and Management, Veterinary College and Research Institute, Namakkal, were selected and grouped into two, comprising of six in each, according to their parity using Completely Randomized Design, to avoid the influence of parity. The cows were fed with standard milch cattle ration, chopped green and dry fodders. The soaked fenugreek seed (100 g per day per animal) was supplemented with cattle feed to six animals in a group daily in the afternoon, rest were treated as control. Feed and fodder consumption of each cow were recorded daily. The study period comprised of 30 days of pre-supplementation, 60 days of supplementation and 30 days of postsupplementation periods. Animals were machine milked and the milk yield was recorded daily at 0500 and 1500 hours. fat, solids not fat (SNF), protein and lactose content were estimated by using Lactoscan (Model no. SL 30, MB Version: 60,
Ser.N:1614). The data were subjected to basic statistical analysis and test of significance as per the methods suggested by Snedecor and Cochran (1989).

\section{Results and Discussion}

The mean daily milk yield (litres) observed for the pre-supplementation, supplementation and post-supplementation periods are furnished in Table 1.

The cows during fenugreek seed supplementation period recorded higher milk yield (8.93 litres) as compared to presupplementation (8.24 litres) and postsupplementation (8.37 litres) periods and the difference was statistically significant $(\mathrm{P}<$ 0.05). The galactopoietic effect of fenugreek might be mediated through an increase in total dry matter intake. Similar observation was made by Tomar et al., (1996) and Abo El-Nor et al., (2007) in buffaloes, Al-Shaikh et al., (1999 and 2002) and Al-Saiady et al., (2007) in goats and Rashwan (1998) in rabbits. The relative improvement in milk production was justified by the earlier findings of increased nutrient digestibility (Abo El- Nor et al., 2007); increased plasma prolactin level in buffaloes (Abo El-Nor, 1999). Moreover, the higher milk production in fenugreek seed feeding could be illustrated on the basis that fenugreek seeds might contain some active components stimulating the hypothalamus or directly to pituitary gland leading to release of prolactin (Basha et al., 1987).

The total solids per cent $(\mathrm{P}<0.01)$ during supplementation period $(13.51 \pm 0.07)$ showed significantly higher value as compared to pre-supplementation (13.18 \pm 0.03) and post-supplementation (13.19 \pm 0.05 ) periods. The carminative, tonic (Fazli and Hardman 1968) and appetite stimulant (Petit et al., 1993) properties of fenugreek seed could have caused increased green and 
dry fodder consumption and the richness of fenugreek seed in protein and free amino acids (Jain and Madhu 1988); vitamins thiamin, niacin, carotene and vitamin $\mathrm{E}$ (Kamal and Yadav 1991); organic substance with sulphur and mineral salts with iron, phosphorus and magnesium (Rosioru et al., 2010) could have improved the dry matter intake there by increased the nutrient availability and absorption which in turn increased the total solids content.

SNF per cent was also significantly higher during fenugreek supplementation period (8.63 \pm 0.03$)$ as compared to presupplementation $(8.54 \pm 0.02)$ and postsupplementation $(8.55 \pm 0.03)$ periods.
Increase in SNF per cent might be ascribed to the effect of fenugreek seed on hypothalamus to stimulate hungriness (appetite centre) in the brain and increase the desire for eating (Petit et al., 1993). Moreover, fenugreek seed contains saponins, which stimulate anaerobic fermentation of organic matter that improve efficiency of utilization of nutrients (Abo ElNor et al., 2007). In addition, it increased the bacterial number in the rumen of lactating cows (Valdez et al., 1986 and Ali et al., 2005) there by increased the organic matter digestibility and the associated effect between acetate and succinate on rumen microflora and lead to improvement of feed efficiency (Abo El-Nor and Kholif, 2005) which in turn improved the solids not fat content.

Table.1 Mean ( \pm SE) values of milk yield (litres), milk composition (per cent) of crossbred dairy cattle

\begin{tabular}{|c|c|c|c|}
\hline $\begin{array}{c}\text { Production } \\
\text { parameters }\end{array}$ & $\begin{array}{c}\text { Pre- } \\
\text { supplementation }\end{array}$ & Supplementation & $\begin{array}{c}\text { Post- } \\
\text { supplementation }\end{array}$ \\
\hline Milk yield* $^{*}$ & $8.24 \pm 0.09^{\mathrm{a}}$ & $8.93 \pm 0.16^{\mathrm{b}}$ & $8.37 \pm 0.22^{\mathrm{a}}$ \\
\hline Total solids $^{* *}$ & $13.18 \pm 0.03^{\mathrm{a}}$ & $13.51 \pm 0.07^{\mathrm{b}}$ & $13.19 \pm 0.05^{\mathrm{a}}$ \\
\hline SNF $^{*}$ & $8.54 \pm 0.02^{\mathrm{a}}$ & $8.63 \pm 0.03^{\mathrm{b}}$ & $8.55 \pm 0.03^{\mathrm{a}}$ \\
\hline Fat $^{* *}$ & $4.64 \pm 0.02^{\mathrm{a}}$ & $4.89 \pm 0.06^{\mathrm{b}}$ & $4.64 \pm 0.03^{\mathrm{a}}$ \\
\hline Total protein $^{* *}$ & $3.12 \pm 0.01^{\mathrm{a}}$ & $3.22 \pm 0.01^{\mathrm{b}}$ & $3.14 \pm 0.01^{\mathrm{a}}$ \\
\hline Lactose $^{*}$ & $4.65 \pm 0.01^{\mathrm{a}}$ & $4.72 \pm 0.01^{\mathrm{bc}}$ & $4.69 \pm 0.04^{\mathrm{ab}}$ \\
\hline
\end{tabular}

Means bearing the same superscript in a row do not differ significantly

** Highly significant $(\mathrm{P}<0.01)$, * Significant $(\mathrm{P}<0.05)$

The mean fat and protein per cent during supplementation period $(4.89 \pm 0.06$ and 3.22 $\pm 0.01)$ were significantly $(\mathrm{P}<0.01)$ higher as compared to pre-supplementation $(4.64 \pm 0.02$ and $3.12 \pm 0.01)$ and post- supplementation $(4.64 \pm 0.03$ and $3.14 \pm 0.01)$ periods. In agreement with higher fat per cent in the present study, Shah and Mir (2004) in cows; and Abo El-Nor (1999) and Abo El-Nor et al., (2007) in buffaloes; and Al-Shaikh et al., (1999) in goats reported that the fenugreek supplementation had higher fat per cent compared to control. This may be attributed to the effect of fenugreek seed on stimulation of pancreatic digestive enzymes and stimulation of the liver to produce and secrete bile rich in bile acids (Platel and Srinivasan, 2001), antioxidant potential (Choudhary et al., 2001, Mc Carthy et al., 2001 and Suja et al., 2002); appetite stimulation and increasing prolactin (Abo El-Nor 1999) and growth hormone release (Alamer and Basiouni, 2005) and activating the udder tissue (Drackley et al., 2001 and Abo El-Nor et al., 2007) there by increasing the flow of milk (Yadav et al., 2011) which in turn helped to improve the fat content. With respect to increased protein percentage during supplementation similar 
observation were made earlier by Tomar et al., (1996), Abo El-Nor (1999) and Abo ElNor et al., 2007. On the contrary, Shah and Mir (2004) reported no change in the protein content of cows fed with crushed fenugreek seed. The mean lactose per cent (4.72) was significantly $(\mathrm{P}<0.05)$ higher during fenugreek supplementation period compared to pre-supplementation (4.65) and postsupplementation (4.69) periods.

From this study we could conclude that crossbred dairy cows supplemented with fenugreek seed during lactation showed better performance in terms of increased milk yield, total solids, fat and protein percentage which in turn improves the net return. Hence, fenugreek seed supplementation can be recommended as a cost effective management measure for improving milk production in dairy cattle.

\section{Acknowledgements}

The authors are thankful to the Dean, Veterinary College and Research Institute, Namakkal for providing the necessary facilities to carry out the work.

\section{References}

Abo El-Nor S A H. 1999. Influence of fenugreek seeds as a galactagogue on milk yield, milk composition and different blood biochemical of lactating buffaloes during mid- lactation. Egypt. J. Dairy. Sci., 27: 231 - 238.

Abo El-Nor S A H. Khattab H M, Al-Alamy H A, Salem F A and Abdou M M. 2007. Effect of some medicinal plants seeds in the rations on the productive performance of lactating buffaloes. Int. J. Dairy Sci., 2: 348 - 355.

Abo El-Nor, S.A.H and S.M. Kholif, 2005. Impact of sodium acetate and sodium succinate supplemental to rations of lactating goats on milk production, milk composition and some ruminal and blood parameters. Egypt. J. of Nutr. Feeds., 8(1): 15 - 25.

Al - Saiady M Y, Alshaikh M A, Mogawer H H,
Al-Mufarrej S I and Kraidees M S. 2007. Effect of feeding different levels of fenugreek seeds on mlik yield, milk fat and some blood hematology and chemistry of Ardi goat. $J$. Saudi Soc. for Agric. Sci., 6(2): 23 - 27.

Alamer, M A and Basiouni G F. 2005. Feeding effects of fenugreek seeds (Trigonella foenum-graecum L.) on lactation performance, some plasma constituents and growth hormone level in goats. Pak. J. Biol. Sci., 8: 1553-1556.

Ali, M.F., M.S. Saleh, N.M. Eweedah and S.A. Mohmoud, 2005. Effect of using chamomile (mtricaria chamomilla) flowers as feed additives on performance of growing lambs under desert farming systems. Egypt. J. Nutr. Feeds., 8: 17 - 137.

Al-Shaikh M, Al-Mufarrej S and Mogawer H H. 2002. The effect of different levels of fenugreek seeds on milk yield of Aradi goat. Department of Animal Production, College of Agriculture King Saudi University.

Al-Shaikh M A, Al-Mufarrej S I and Mogawer H H. 1999. Effect of fenugreek seeds (Trigonella foenum-graecum L.) on lactational performance of dairy goat. $J$. Appl. Anim. Res., 16: 177 - 183.

Basha L A, Rokaya M, Hussein M, Badawi M and Abdalla A M. 1987. The influence of Trigonella foenum-graecum on prolactin release in female albino rats during different phases of reproductive life. J. Drug Res. Egypt., 17: 1 - 12.

Choudhary D, Chandra D, Choudhary S and Kale R K. 2001. Modulation of glyoxalase, glutathione S-transferase and antioxidant enzymes in the liver, spleen and erythrocytes of mice by dietary administration of fenugreek seeds. Food and Toxicology, 39: 989 - 997.

Drackley J K, Overton T R and Douglas G N. 2001. Adaptations of glucose and long chain fatty acid metabolism in liver of dairy cows during periparturient period. J. Dairy Sci., 84: E100 - E112.

Fazli F R Y and Hardman R. 1968. The spice fenugreek (Trigonella foenum graecum): Its commercial varieties of seed as a source of diosgenin. Trop. Sci., 10: 66 - 78.

Fotopoulos, C., 2002. Marketing. In: Petropoulos GA (ed) Fenugreek-The genus Trigonella. 
Taylor and Francis, London. pp. 183 - 195.

Jain S C and Madhu A. 1988. Regulation of trigonellin in Trigonella species by chemical mutagenic treatments. Indian Drugs, 26: 14 16.

Jensen R. 1992. Fenugreek, overlooked but not forgotten. UCLA Lactation Alumni News letter., 1: 2-3.

Kamal R. and Yadav R. 1991. Flavonoids from Trigonella polycerta in-vivo and invitro. Journal of Phytological Research, 4: 161 165.

Khattab H M, Abo El-Nor S A H, Kholif S M, ElSayed H M, Abd El-Shaffy O H and Saada M. 2010. Effect of different additive sources on milk yield and composition of lactating buffaloes. Livest. Sci., 131: 8 - 14.

Mc Carthy T L, Kerry J P, Kerry J F, Lynch P B and Buckley D J. 2001. Evaluation of the antioxidant potential of natural food/plant extracts as compared with synthetic antioxidants and vitamin $\mathrm{E}$ in raw and cooked pork patties. Meat Sci., 57: 45-52.

Mishra U K, Kanesh J S, Mandal A K, Das R K, Rayaguru K and Parija S C. 2006. Potentials of herbal galactogogues in milk production in ruminants. The Indian Cow . Pp: $44-56$

National Dairy Development Board, 2012. Department of Animal Husbandry, Dairying and Fisheries, Ministry of Agriculture, Government of India. Last updated: Feb 29, 2012.

Petit P, Sauvaire Y, Ponsin G, Manteghetti M, Fave A and Ribes G. 1993. Effects of a fenugreek seed extract on feeding behaviour in the rat: metabolic-endocrine correlates. Pharmacol. Biochem. Behav., 45(2): 369 374.

Platel K. and Srinivasan K. 2001. Studies on the influence of dietary spices on food transit time in experimental rats. Nutr. Res., 21:
$1309-1314$.

Rashwan A A. 1998. Effects of dietary additions of anise, fenugreek and caraway on reproductive and productive performance of New Zealand White rabbit does. Egyptian Rabbit Sci., 8(2): 157 - 167.

Rosioru G, Simeoni P I, Craciun C and Ardelean A. 2010. Trigonella foenum-graecum (sicklefruit fenugreek) Seeds - a natural hepatoprotector that prevents ethanol-induced toxicity. Annuals of RSCB Vol. XV, Issue 2

Shah M A and Mir P S. 2004. Effect of dietary fenugreek seed on dairy cow performance and milk characteristics. Can. J. Anim. Sci., 84: 725 - 729.

Shane-McWhorter L. 2001. Biological complementary therapies: A focus on botanical products in diabetes. Diabetes Spectrum, 14: 199 - 208.

Suja P, Anuradha R C V and Viswanathan P. 2002. Gastroprotective effect of fenugreek seeds (Trigonella foenum graecum) on experimental gastric ulcer in rats. Ethnopharmacol., 81: 393 - 397.

Tiran D. 2003. The use of fenugreek for breast feeding women. Complem. Ther. Nurs. Midwif., 9: 155 - 156.

Tomar K S, Singh V P and Yadav R S. 1996. Effect of feeding maithy (Trigonella foenumgraecum L.) and chandrasoor ( Lepidium sativum L.) seeds on milk and blood constituents of Murrah buffaloes. Indian J. of Anim. Sci., 66: 1192 - 1193.

Valdez, F.R., L. J. Bush, A.L. Goetsch and F.N. Owens, 1986. Effect of steroidal sapogenins on ruminal fermentation and on production of lactating dairy cows. J. Dairy Sci., 69: 1568 - 1575.

Yadav R, Kaushik R and Gupta D. 2011. The health benefits of Trigonella foenumgraecum: a review 1(1): 32 - 35 .

\section{How to cite this article:}

Revathi, P., D. Anandha Prakash Singh, V. Ramesh Saravana Kumar, A. K. Thiruvenkadan and Bharathy, N. 2020. Effect of Fenugreek Seed Supplementation on Milk Yield and its Composition of Crossbred Dairy Cattle. Int.J.Curr.Microbiol.App.Sci. 9(09): 676-680. doi: https://doi.org/10.20546/ijcmas.2020.909.085 